\title{
How local wisdom-based story calendar media improve patriotism character of elementary students?
}

\author{
Moh. Farizqo Irvan *, Ali Mustadi \\ Department of Primary Education, Graduate School of Universitas Negeri Yogyakarta. \\ Jalan Colombo No. 1, Yogyakarta 55281, Indonesia \\ * Corresponding Author. E-mail: mohfarizqo.2018@student.uny.ac.id
}

Received: 14 September 2020; Revised: 9 November 2020; Accepted: 21 November 2020

\begin{abstract}
This research aims to determine the effectiveness of local wisdom-based story calendar media in improving students' patriotism. The type of research is pseudo-experimental by using a nonequivalent control group design. The study population is the fourth-grade students of an elementary school in Ngaliyan District, Semarang, in the even semester, the academic year 2019/2020. The subjects were determined by implementing random cluster sampling. The influence of the media on students' patriotism was measured using $\mathrm{n}$-gain and independent $\mathrm{t}$-tests. The results showed that the n-gain of students' patriotism in the experimental class I and experimental class II were higher than the control class, such as $0.37,0.39$, and 0.07 with a moderate category for experimental class and low category for control class. Independent t-test results also showed that the value (p) was 0.025 and $0.044 \leq 0.05$, so significant differences in students' patriotism characterize the experimental dan control class. So, it can conclude that the local wisdom-based story calendar media effectively improves students' patriotism in the fourth grade of elementary school.
\end{abstract}

Keywords: story calendar, local wisdom, patriotism character, elementary school.

How to Cite: Irvan, M., \& Mustadi, A. (2021). How local wisdom-based story calendar media improve patriotism character of elementary students?. Jurnal Prima Edukasia, 9(1), 135-144. doi:https://doi.org/10.21831/jpe.v9i1.34458

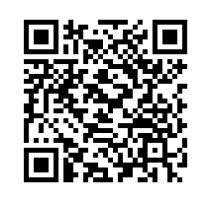

\section{Introduction}

Since life is getting complex, students in the 21 st century have been challenged to be a competent and skilful human being, without disregarding their characters and national identity, especially in this globalization era (Altintaş \& Karaaslan, 2019). It is implied in the current educational life to create students who are skilful and have character. Hadiansyah et al. $\left(2017\right.$, p.5) stated that education in $21^{\text {st }}$ should emphasize the importance of character education and basic literacy. It is in line with the Character Education Improvement (Penguatan Pendidikan Karakter) Program conducted by the Indonesian Ministry of Education and Culture (Kemdikbud). One of the characters developed is patriotism.

The character of patriotism is an attitude that shows the love of citizens for their homeland. This love can be manifested in the form of attitudes and behaviour. Kodelja (2011, p.127) stated that patriotism is a virtue and the foundation of morality. It means that patriotism as a form of a love of citizens for their country becomes the basis for behaving in national life. This is in line with Anderson \& Ulfa (2018, p.147), who stated that patriotism is the highest form of appreciation to the nation, manifested through acts and ways of thinking that show loyalty and care to the nation.

Furthermore, Uzakbayeva, Zhalgasova, Beisembayeva, \& Kosherbayeva (2014, p.677) stated that patriotism is not just a sense of unity by only learning about native language and literature, but a sense of unity to remain caring and loyal to the region of origin. This form of loyalty and concern can be realized by actively participating in activities that support the nation's progress in any form. As good citizens, they should feel proud to be part of a country and have a passion that presents a ready attitude to defend the country against all forms of threats, challenges, obstacles, and disturbances that can endanger the survival of the nation and state.

Regarding the patriotism character, it cannot be separated from nationalism. Nationalism is a principle that signifies an adherence of citizens to a nation (Lo \& Chan, 2020; Sofyaningsih, 2014). Heimonen \& Hebert (2012, p.157) stated that nationalism is used to describe two important phenomena. First, the attitude of members of a nation to care about the identity of their country. Second, actions were 
Jurnal Prima Edukasia, 9 (1), 2021 - 136

Moh. Farizqo Irvan, Ali Mustadi

taken by citizens to defend their fate. Based on the statements before, it can be understood that patriotism is related to nationalism. Nationalism is a view to being loyal and loves the nation, while patriotism is an attitude arising from someone who understands nationalism. Nationalism can be taught through nationalistic education to cultivate people's knowledge about national identity, patriotism, and loyalty to their nation-state (Hand \& Pearce, 2011, p.407). Furthermore, Hjerm (2010, p.45) \& Spyrou (2011, p.532) reveal that nationalism is a form of responsibility that should be developed through character education. Character education is a medium to build nationalism and patriotism, which plays a crucial role in creating future generations that understand their national identity.

However, based on a survey conducted to identify the citizens' patriotism showed that $34.1 \%$ of the societies are not proud to be Indonesians (Tukiran, 2014, p.31). The survey results also showed that $75 \%$ of the young generations prefer foreign products rather than local products, and $65 \%$ of them have low awareness of Indonesians' problems (Nudji, 2015, p.408). Both surveys are in line, shown by the facts found in society. Based on the results of the interview conducted to the fourth-grade students in Semarang, it revealed that: (1) There are garbages found on the floor even when the class has been started, (2) the students are not able to use Bahasa Indonesia properly and fluently in the learning process, and (3) The students have no idea about their own cultures (in their region). Based on these problems, it is important to build their patriotism since the early childhood. The efforts on building and developing their characters can be integrated in school, especially in the learning process.

The integration of the learning process by implementing character education is a part of Curriculum 2013 that facilitates students' cognitive, affective, and psychomotor domains at an equivalent level. Agboola \& Tsai (2012, p.168) revealed that the classroom is an effective environment to develop students' character, besides in the home. The development of character education in the learning process can be conducted optimally by utilizing the learning media (Pasandaran, Katuuk, \& Sendouw, 2019, p.271). The learning media can be used to convey the message contained in the learning process. One alternative media that can be used in building students' character is the local wisdom-based story calendar. Local wisdom-based story calendar is a medium developed based on the elements of local wisdom, especially in story development as one of the main elements of the story calendar.

A story calendar is a media organized by arranging several pieces of paper containing messages, as a calendar used to teach basic literacy, such as writing and reading comprehension (USAID, 2014, p.48). Story calendar is a form of picture storybooks' development, consists of pictures, stories, and activities that can improve students' literacy skills. Picture storybook as learning media have a primary key; there is a relationship between pictures and messages conveyed through text (Yulistia, 2019, p.174). Gutiérrez, Puello, \& Galvis (2015, p.49) stated that pictures could attract students' attention to understand the learning material. Another element is a fictional story containing moral lessons as the stimulus in building children's characters (Pulimeno, Piscitelli, \& Colazzo, 2020, p.13). Activities that reinforce students' literacy skills are reading and writing and building their characters (Dewi \& Isnarmi, 2018, p.351).

The study on the effectiveness of learning medium that contains pictorial stories in improving students' character had been conducted by Sriati (2015, p.180), which revealed that there are any improvements in students' character that are taught by using picture storybooks. Tyra $(2012$, p.11) revealed that picture storybooks are effective children literature to build students' character in early childhood. Children's character can be taught through the storybooks' lessons (Nurgiyantoro, 2010, p.25).

Local wisdom-based learning can help the students understand the learning materials easily since they can be found in daily life. Many positive impacts are using the local wisdom as a source of learning for students. Students are easier to understand the subject, get in touch with the actual environment, inspire to apply knowledge, and encourage them to maintain the environment (Suryanti et al., 2020, p.103). Erviana (2018, p.227) stated that the social environment could help the learning process because society and culture are science source to develop students knowledge. Local wisdom-based learning is better than conventional learning since it applies to the student's daily life, and the learning will be more meaningful (Uge, Neolaka, \& Yasin, 2019, p.375). Significant learning can reinforce the students to construct their knowledge and concepts, and it will help the students to remember and understand the learning material easily (Sung, Hwang, \& Chang, 2015, p. 308; Vallori, 2014, p.199). Besides making students easier in understanding the material, the local wisdom value can also be used as a medium to build students' nationalism (Syarif, 2019, p.194). 
Jurnal Prima Edukasia, 9 (1), 2021 - 137

Moh. Farizqo Irvan, Ali Mustadi

The study on the effectiveness of local wisdom-based media in improving students' patriotism was also conducted by Nur $(2017$, p.9) by developing a local wisdom-based medium that enhances students' nationalism. Also, Bria (2018, p.38) reinforces the internalization of local wisdom in the learning process since it plays roles in preserving Indonesian unity and integrity as forms of patriotism. Anggraini \& Kusniarti (2017, p.23) revealed that integrating local wisdom in the learning process could improve students' awareness of their culture to reduce the negative impact of globalization.

Regarding the problems, the local wisdom-based story calendar can be an alternative media in improving students' patriotism. Story calendar and local wisdom-based learning have several advantages that can reinforce the improvement of students' patriotism. Therefore, it is necessary to examine the extent of local wisdom-based story calendar media's effectiveness in improving students patriotism.

\section{Method}

The type of research is quantitative, by implementing quasi-experiments. Also, the researcher implemented a nonequivalent control group design (see Table 1). This experimental research design consists of three classes as samples. Three classes are divided into two groups. The first group is the control class, and the second one is the experimental class. The experimental class consists of two classes (experimental class I and II) that get treatment use the local wisdom-based story calendar media in the learning process. The Independent variable in this research is students' patriotism character in the fourth grade of elementary school.

Table 1. Nonequivalent Control Group Design

\begin{tabular}{cccc}
\hline Groups & Pre-test & Treatment & Post-test \\
\hline Experimental I & $\mathrm{CSA}_{1}$ & Local wisdom-based story calendar media & $\mathrm{CSA}_{2}$ \\
Experimental II & $\mathrm{CSA}_{1}$ & Student Textbook & $\mathrm{CSA}_{3}$ \\
Control & $\mathrm{CSA}_{1}$ & $\mathrm{CSA}_{4}$ \\
\hline
\end{tabular}

The study was conducted in the 2019/2020 academic year, while the population consisted of 83 fourth grade students (10-11 years old) from three public schools in Semarang, Indonesia. The researcher implemented random cluster sampling to determine the experimental and control classes randomly. There were 27 students (12 male students and 15 female students) at SD Negeri Ngaliyan 01 as experimental class I, while 27 students (10 male students and 17 female students) at SD Negeri Bojong Salaman 01 belong to experimental class II, and 29 students (15 male students and 14 female students) belong to control class. Students in the experimental class I and II obtained the treatment, as taught using a local wisdom-based story calendar in the learning process. In contrast, students in the control class were taught using a student textbook, like conventional learning.

The data were collected by using a self-assessment scale. The research instrument was in the form of a self-assessment sheet for the students' patriotism. The expert checked the validity of the instrument. The data were collected before and after the learning process. Students are asked to fill out the selfassessment sheets before the learning process (pre-test), both in the control class and experimental classes. Then, the learning process in control and experimental classes was differentiated. The learning process in experimental class I and II were conducted by teaching the students using the local-wisdom story calendar, while the control class was taught conventionally using a student textbook (as usual). The learning processes consisted of five meetings. At the end of the fifth lesson, students in the control class and experimental classes were asked to fill out the self-assessment sheets regarding the patriotism character. Thus, the fourth-grade students' patriotism data, before and after obtaining the treatment or using local wisdom-based story calendar, were obtained.

Data on the students' patriotism were analyzed qualitatively and quantitatively. Qualitative data analysis was conducted using n-gain to determine the categories of improvement of students' patriotism for each class. Meanwhile, quantitative data analysis was performed using an independent t-test. An Independent t-test can be used by comparing the post-test data on students' patriotism character. However, before comparing the data, prerequisites test were conducted, such as normality test and homogeneity test. After the prerequisite tests were conducted, then the data were anayzed by using an independent t-test. The independent t-test category is accepted if $\alpha \leq 0.05$. Thus, it can be concluded that there is a significant difference between students' patriotism that are taught using local wisdombased story calendar and students' who are taught using conventional media. It can also be interpreted 
Jurnal Prima Edukasia, 9 (1), 2021 - 138

Moh. Farizqo Irvan, Ali Mustadi

that the local wisdom-based story calendar is effective in improving the fourth-grade students' patriotism character.

\section{Result and Discussion}

The improvement of students' patriotism can be measured by comparing their patriotism character before and after obtaining the treatment, both in control class and experimental classes (I and II). The following table shows the improvement of students' patriotism character in the fourth grade of elementary school.

Table 2. Pre- and Post-test Score on Student's Patriotism Character

\begin{tabular}{cccccc}
\hline \multirow{2}{*}{ Groups } & \multicolumn{2}{c}{ Mean } & \multirow{2}{*}{ Gain } & \multirow{2}{*}{ Criteria } \\
\cline { 2 - 3 } & Pre-test & Post-test & & Moderate \\
Experimental I & 73.32 & 83.24 & & 0.37 & Moderate \\
Experimental II & 69.81 & 81.67 & & 0.39 & Low \\
Control & 68.10 & 70.34 & 0.07 & .
\end{tabular}

Table 2 showed that all classes experienced an increase in their patriotism character, both in the control class and in the experimental classes. However, the increases in each class were various. The data showed that students' scores in experimental class I and experimental class II had increased, such as 9.92 and 11.86, or higher than the control class. The gain scores in the experimental class I and II were 0.37 and 0.39 , categorized as moderate. Thus, it can be concluded that the students' patriotism in the experimental class I and II are higher than the control class after obtaining the treatment. Hence, to find out whether there is any significant difference between the students' patriotism in the experimental class I, experimental class II, and the control class, it was done by using a t-test. The following table results from the analysis of students' patriotism character by using an independent $t$-test.

Table 3. Independent t-test Results on Students' Patriotism Character

\begin{tabular}{cccc}
\hline Groups & Mean & Sig. (2-tailed) & Explanation \\
\hline Control & 70.34 & 0.025 & There are significant differences \\
Exp I & 83.24 & & There are significant differences \\
\hline Control & 70.34 & 0.044 & \\
Exp II & 81.67 & 0 &
\end{tabular}

The average post-test score of students' patriotisms in experimental class I (83.24) and experimental class II (81.67) was higher than the control class (70.34). Table 3 showed that the p-value in the experimental class I and the control class is 0.025 , while in the experimental class II and the control class is 0.044 . The p-value in both groups shows that both scores are smaller than 0.05 . In other words, there is a significant difference between students' patriotism that are taught using local wisdombased story calendar and students' who are taught using conventional media. Thus, it can be concluded that the local wisdom-based story calendar effectively improves the students' patriotism character in the fourth grade of elementary school.

Character is one of the elements that determine someone's life path. This is in line with (Lickona, 2004), who stated that "character is destiny" or character is someone's destiny. It can be defined that someone's destiny can be determined through his or her character. This also illustrates the importance of a character in a person's life. Good character cannot be built and developed by itself. Building someone's characters takes processes from early childhood. Through education, the patriotism character can be built in each level, such as elementary level. Character is an abstract thing; hence, it needs certain considerations.

Elementary school students consisted of 7-12 years old children or in the concrete operational stage, such as early-grade and high-grade students. High-grade students in elementary school have high interest and high curiosity in certain subjects or courses, measure the achievement in school and tend to be in certain groups or group games (Izzaty et al. Another opinion is conveyed by Djamarah (2015, p.125), who stated that the main characteristic of the fourth-grade students (as high-grade students) in elementary school is having a high interest in concrete things. There is a tendency to compare practical work, curiosity and realism, specialization of subjects. In the $11^{\text {th }}$ years, children need teachers or adults, and they feel delightful in the group games.

The fourth-grade students have not been able to think abstractly, and they can only understand the real concept or concrete experience. There are three characteristics of students at the concrete 
Jurnal Prima Edukasia, 9 (1), 2021 - 139

Moh. Farizqo Irvan, Ali Mustadi

operational stage, such as (1) students only understand everything visible, (2) students have not been able to think abstractly even though they can think logically and systematically, and (3) students need to get real experiences by themselves, especially in the process of understanding concept (Jhonson, 2008, p.54). This fact also influences building students' character, and they need assistance or concrete means in interpreting the character. One of the media needed in character education is a learning medium suitable for the development stages of elementary school students at the concrete operational stage. This is in line with Meidl \& Meidl (2009, p.242), who stated that character education could be integrated by developing designs, teaching materials, and learning media based on noble character values. One of the learning media that can accommodate this condition is the local wisdom-based story calendar.

The local wisdom-based story calendar is a development of picture storybooks (in the form of a calendar) with a different story every day. The story calendar's main elements are pictures, stories, and activities that can reinforce the development of students' literacy skills. According to Karpouza, Zampanioti, \& Karakitsios (2014, p.5) and Farindhani \& Wangid (2019, p.96-97), the criteria for selecting and developing instructional media in the form of books for elementary school students must consider content, titles, illustrations/pictures, and the knowledge. Also, illustrations have their charm for the students. Stewig (2013, p.273) stated that in children's book illustrations, the message of the story is reinforced by using attractive colours. This is in line with Moore \& St. George (1991, p.161) that early childhood and elementary school students choose books based on their appearance and illustration. Thus, the selection of books and learning media must be suitable for students' needs, such as containing illustrations and attractive colours.

The first element of the local wisdom-based story calendar medium is related to illustrations and pictures. Shabiralyani et al. (2015, p.226) and (Verhallen \& Bus, 2011) stated that visual media, for example, images, affect the learning process. The use of pictures in the learning process can motivate and attract students' attention. This is in line with Kasmaienezhadfard, Pourrajab, \& Rabbani (2015, p.83) and Yang, Cheng, \& Chou (2016, p.4), who stated that images have an important role in learning media and can be used in the form of books. Pictures can help the students to understand the stories (Dunn \& Finley, 2010, p.34). Aukerman \& Schuldt (2016, p.268) stated that pictures could help students understand abstract concepts. Pictures can make the abstract thing turn into a concrete thing for students. Thus, students can easily understand the story through the pictures or illustrations in the local wisdombased story calendar to improve their patriotism character.

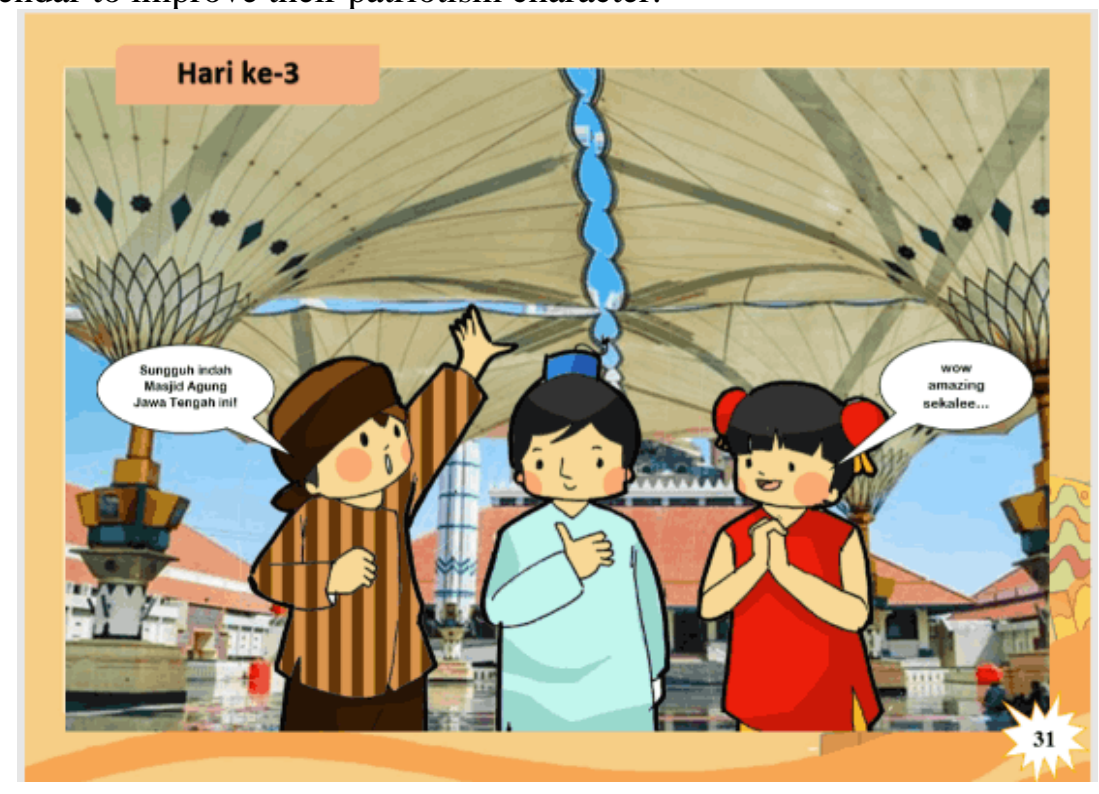

Figure 1. Elements in Local Wisdom-based Story Calendar Media

The second element of the local wisdom-based story calendar that reinforces students' patriotism is the story. The story in the calendar contains moral messages related to the patriotism character. It can be concluded that the story can be used as a medium for strengthening the character education. Muhtarom (2020, p.1197) stated that using story methods in textbook to insert value concepts is very useful for improving students' understanding. The story in the storybook connected positively connected 
to social, cognitive, behaviour, and emotional development (Kohm, Holmes, Romeo, \& Koolidge, 2016, p.128).

Furthermore, Turan \& Ulutas (2016, p.169) stated that learning media that contain stories and pictures could be effective for character education taught in the class. Furthermore, a medium that containing stories and pictures can link children's imaginary world with the real world. Character values can be transmitted through a story and fun activities. Learning media that contain pictorial stories should contain character values since by building the students' character; it will be easier to use a medium that attracts their attention (Gül \& Atay, 2018, p.2). Almerico (2014, p.3) and O'Sullivan (2004, p.642) revealed that the easiest way to teach characters to children is through literature, by utilizing stories to convey moral messages. The characters in the story can be role model for students to behave with their environment (Sanchez \& Stewart, 2006, p.15). By acquiring positive characters in the story, the teacher can guide the students to implement positive attitudes.

Kohlberg \& Hersh (1977, p.54) stated that the theory of children's moral development, it consists of three levels: the pre-convention level, the convention level, and the post-convention level. Each stage is developed into two stages. Kohlberg's theory of moral development was developed based on Piaget's theory of cognitive development, and the fourth-grade students are included in the pre-conventional level. There are two stages at the pre-conventional level: the first stage is obedience and punishment orientation when children accept the rules without asking the reasons. Meanwhile, the second stage is instrumental orientation, when children's behaviour is based on reciprocal consequences. Thus, the selection of learning media in the form of stories should contain positive moral values as role models for the children's behaviour.

Another evidence that local wisdom-based story calendar medium can improve students' patriotism character is the local wisdom contained in the story. Through local wisdom-based learning, students can understand and recognize their own culture, and the sense of caring and preserving their local wisdom is built. Of course, this character needs to be taught to be formed optimally. The formation of students' attitudes can be done through local wisdom-based character education (Suhartini et al., 2019 , p.280). Character education is conducted by integrating elements of local wisdom into educational materials. This is in line with Rischa, Abdul, \& Winarno (2019, p.159), who stated that nationalism could be built by integrating the local wisdom in the students' region.

The third element of the local wisdom-based story calendar that reinforces students' literacy skills is activity. Literacy activities contained in the local wisdom-based story calendar are reading comprehension and writing stories (Figure 2). Gilmore \& Howard (2016, p.218) stated that a medium containing pictorial stories could improve students' reading comprehension and writing skills and give moral values from stories in picture storybooks. Thus, the local wisdom-based story calendar with pictures and stories can reinforce the improvement of students' patriotism and improve students' literacy skills.

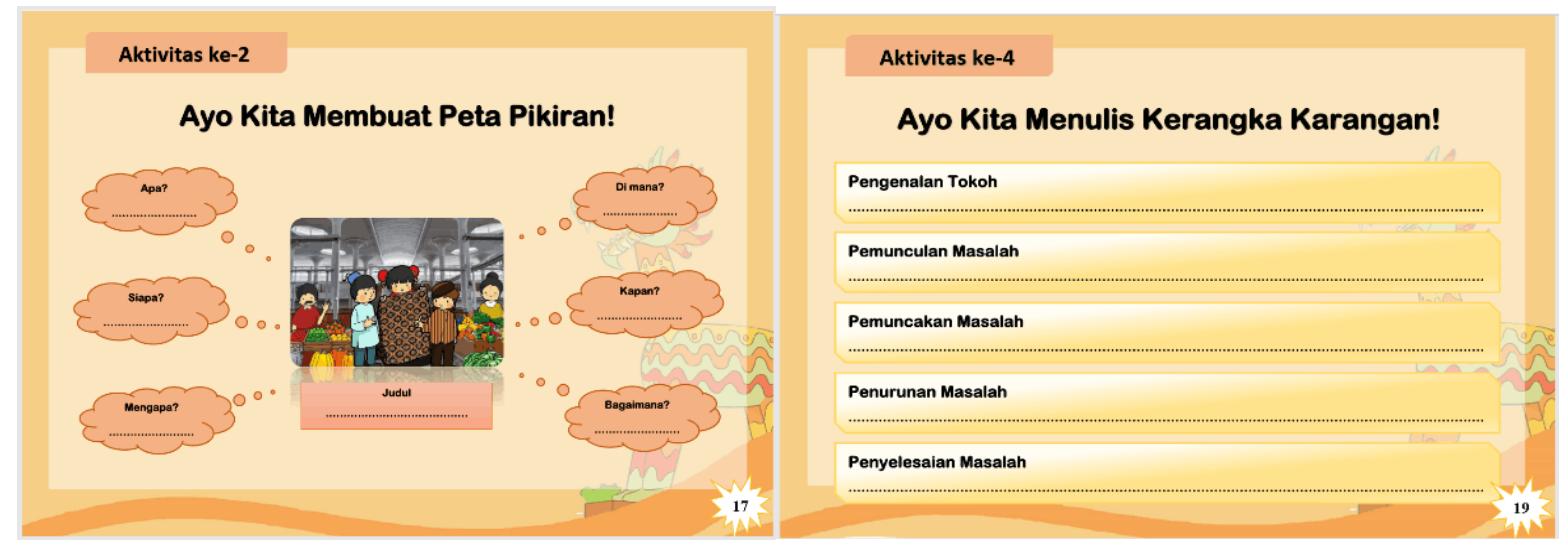

Figure 2. Literacy Activities in Local Wisdom-Based Story Calendar Media

The improvement of students' literacy skills (such as reading comprehension and writing skills) and building students' patriotism character is related to one another. As a product of literacy activities, the story can be categorized as children literature. Children literature contains moral values and messages that can be used as a form of character education. Crozier \& Sileo (2005, p.27) stated that writing social stories can build students' attitudes and personalities. This is in line with Chohan (2011, 
p.39) and Hodhod, Cairns, \& Kudenko (2010, p.2) that by conducting a literacy activity in writing stories, students' morale can be built. When writing, students try to understand the positive values and messages in the story (Harsanti, 2017, p.625).

Furthermore, as a literacy activity, writing a story can affect students' affective domain. When students can adequately achieve one competency, it will affect other related competencies. Thus, the patriotism character and students' literacy skills can be improved at the same time by using a local wisdom-based story calendar.

However, even though the results of this study indicate that the local wisdom-based story calendar is effective in improving students' patriotism, there are several limitations of this study. The research was supposed to be conducted in a longer time, and it makes the data of students' patriotism is still limited to the moral feeling stage, not at the moral doing stage. Therefore, it is necessary to conduct further researches with longer time and various data collection techniques. Also, additional samples are also needed to obtain more comprehensive data. This study only focused on the patriotism character, which is included in the affective domain, and in further research, other variables such as cognitive and psychomotor domains can be examined to determine the effectiveness of local wisdom-based story media in the learning process.

\section{Conclusion}

The results showed that the fourth-grade students in the experimental class had a higher patriotism character than the students in the control class. There is an increase in the average score of patriotism character in each class. However, the improvement in the patriotism character in both experimental classes was more significant than in the control class. The average scores in both experimental classes were higher than the average score of the control class. Thus, it can be concluded that the local wisdombased story calendar is effective in improving the elementary students' patriotism character.

However, even though this research indicates that a local wisdom-based story calendar can improve students' patriotism character, this study has several limitations. First, the time limit makes the data on the student's patriotism are still at the moral feeling stage and have not reached the moral doing stage. Second, the number of samples is still limited. Third, the research only focused on improving the students' character.

Based on the conclusion above, there are some recommendations proposed as follows. First, teachers are expected to use the appropriate learning media to teach character education for primary students. Second, teachers can use the local wisdom-based story calendar media to teach other domains. For example, teacher use this media to teach reading comprehension for the cognitive domain and writing narrative skills for psychomotor domains. Third, this study is expected to give knowledge and experience to increase innovation in the learning process. Finally, further research requires a longer time, various data collection techniques, various research variables, and larger samples to complete this research.

\section{References}

Almerico, G. M. (2014). Building character through literacy with children's literature. Research in Higher Education Journal, 26, 1-13.

Altintaş, I. N., \& Karaaslan, H. (2019). Study on effective citizenship education and its dimensions. Universal Journal of Educational Research, 7(7), 1567-1579. https://doi.org/10.13189/ujer.2019.070711

Anderson, I., \& Ulfa, M. (2018). Penerapan nilai cinta tanah air pada pembelajaran pendidikan kewarganegaraan di kelas IV sekolah dasar. Jurnal Gentala Pendidikan Dasar, 3(1), 145-162. https://doi.org/10.22437/gentala.v3i1.6776

Anggraini, P., \& Kusniarti, T. (2017). Character and local wisdom-based instructional model of bahasa Indonesia in vocational high schools. Journal of Education and Practice, 8(5), 23-29. https://www.iiste.org/Journals/index.php/JEP/article/view/35461

Aukerman, M., \& Chambers Schuldt, L. (2016). "The pictures can say more things": Change across time in young children's references to images and words during text discussion. Reading Research Quarterly, 51(3), 267-287. https://doi.org/10.1002/rrq.138 
Jurnal Prima Edukasia, 9 (1), 2021 - 142

Moh. Farizqo Irvan, Ali Mustadi

Bria, M. E. (2018). Penguatan semangat nasionalisme di daerah perbatasan melalui pendidikan kewarganegaraan berbasis kearifan lokal. Jupiis: Jurnal Pendidikan Ilmu-Ilmu Sosial, 10(1), 38. https://doi.org/10.24114/jupiis.v10i1.8379

Chohan, S. K. (2011). Any letter for me? Relationships between an elementary school letter writing program and student attitudes, literacy achievement, and friendship culture. Early Childhood Education Journal, 39(1), 39-50. https://doi.org/10.1007/s10643-010-0438-5

Crozier, S., \& Sileo, N. M. (2005). Encouraging positive behavior with social stories. Teaching Exceptional Children, 37(6), 26-31. https://doi.org/10.1177/004005990503700603

Dewi, Z., \& Isnarmi. (2018). Penanaman karakter dalam program gerakan literasi sekolah di SMP negeri 18 Padang. Journal of Civic Education, 1(4), 350-362.

Djamarah, S. B. (2015). Psikologi belajar. Rineka Cipta.

Erviana, V. Y. (2018). Pengembangan perangkat pembelajaran berbasis sosiokultural bagi siswa sekolah dasar. Jurnal Prima Edukasia, 6(2), 166-176.

Erviana, V. Y., \& Mustadi, A. (2016). Pengembangan perangkat pembelajaran tematik-integratif berbasis sosiokultural bagi siswa kelas 1 SD Serayu. Jurnal Prima Edukasia, 4(2), 222. https://doi.org/10.21831/jpe.v4i2.8970

Farindhani, D. A., \& Wangid, M. N. (2019). Scientific-based pictorial storybook with project-based learning method for improving the critical thinking skills of elementary school students. Jurnal Prima Edukasia, 7(1), 94-105. https://doi.org/10.21831/jpe.v7i1.8807

Gilmore, L., \& Howard, G. (2016). Children's books that promote understanding of difference, diversity and disability. Journal of Psychologists and Counsellors in Schools, 26(2), 218-251. https://doi.org/10.1017/jgc.2016.26

Gül, M. K., \& Atay, M. (2018). An analysis of values in children's picture books in Turkish for 5-6 year-old children. SHS Web of Conferences, 48(August), 1-11. https://doi.org/10.1051/shsconf/20184801062

Gutiérrez, K. G. C., Puello, M. N., \& Galvis, L. A. P. (2015). Using pictures series technique to enhance narrative writing among ninth grade students at institución educativa simón araujo. English Language Teaching, 8(5), 45-71. https://doi.org/10.5539/elt.v8n5p45

Hadiansyah, F., Djumala, R., Gani, S., Hikmat, A. an A., Nento, M. N., Hanifah, N., Miftahussururi, \& Akbari, Q. S. (2017). Literasi budaya dan kewargaan. Kementerian Pendidikan dan Kebudayaan Republik Indonesia.

Hand, M., \& Pearce, J. (2011). Patriotism in British schools: teachers' and students' perspectives. Educational Studies, 37(4), 405-418. https://doi.org/10.1080/03055698.2010.539775

Harsanti, A. G. (2017). Pendidikan karakter melalui pembelajaran sastra. Seminar Nasional Bahasa Dan Sastra Indonesia Dalam Konteks Global, 1(2), 623-636. https://doi.org/10.15294/jpii.v1i2.2140

Hebert, D. G., \& Kertz-Welzel, A. (2012). Patriotism and nationalism in music education. Routledge.

Hjerm, M. (2010). Education, xenophobia and nationalism: A comparative analysis. Journal of Ethnic and Migration Studies, 27(1), 37-60. https://doi.org/10.1080/13691830124482

Hodhod, R., Cairns, P., \& Kudenko, D. (2010). Fostering character education with games and interactive story generation. Designing Games for Ethics: Models, Techniques and Frameworks, February 2016, 208-233. https://doi.org/10.4018/978-1-60960-120-1.ch014

Johnson, A. P. (2008). Teaching reading and writing: A guidebook for tutoring and remediating students. R\& L Education.

Karpouza, E., Zampanioti, A., \& Karakitsios, A. (2014). Children's books in education: teacher's and student's selection criteria. International Annual Conference The Child and the Book Conference "Time, Space, and Memory in Literature for Children and Young Adults", 1, 1-9.

Kasmaienezhadfard, S., Pourrajab, M., \& Rabbani, M. (2015). Effects of pictures in textbooks on students' creativity. Multi Disciplinary Edu Global Quest, 2(14), 83-96.

Kodelja, Z. (2011). Is education for patriotism morally required, permitted or unacceptable? Studies in 
Jurnal Prima Edukasia, 9 (1), 2021 - 143

Moh. Farizqo Irvan, Ali Mustadi

Philosophy and Education, 30(2), 127-140. https://doi.org/10.1007/s11217-011-9233-z

Kohlberg, L., \& Hersh, R. H. (1977). Moral development: A review of the theory. Theory Into Practice, 16(2), 53-59. https://doi.org/10.1080/00405847709542675

Kohm, K. E., Holmes, R. M., Romeo, L., \& Koolidge, L. (2016). The connection between shared storybook readings, children's imagination, social interactions, affect, prosocial behavior, and social play. International Journal of Play, 5(2), 128-140.

https://doi.org/10.1080/21594937.2016.1203895

Lickona, T. (2004). Educating for character : how our schools can teach respect and responsibility. Bantam.

Lo, W. Y. W., \& Chan, S. J. (2020). Globalism, regionalism and nationalism: the dynamics of student mobility in higher education across the Taiwan Strait. Discourse, 41(4), 587-603. https://doi.org/10.1080/01596306.2018.1516198

Meidl, C., \& Meidl, T. (2009). Empowering childrens's global citizenship. Journal of Childhood Education, 85(4), 242-258.

Moore, P. A., \& St. George, A. (1991). Children as information seekers: the cognitive demands of hooks and library systems. School Library Media Quarterly, 19(1), 161-168.

Muhtarom, T. (2020). The comparison of nationalism and civic education value between indonesian and malaysian elementary school textbook. Elementary Education Online, 19(3), 1185-1199. https://doi.org/10.17051/ilkonline.2020.728015

Nurdin, E. S. (2015). The policies on civic education in developing national character in indonesia. International Education Studies, 8(8), 405-411. https://doi.org/10.5539/ies.v8n8p199

Nurgiyantoro, B. (2010). Sastra anak dan pembentukan karakter. Cakrawala Pendidikan, 1(3), 25-40. https://doi.org/10.21831/cp.v1i3.232

O'Sullivan, S. (2004). Books to live by: Using children's literature for character education. Reading Teacher, 57(7), 640-645.

Pasandaran, S., Katuuk, D., \& Sendouw, R. H. E. (2019). Analysis of teacher strategy in developing character learning at school. International Journal of Recent Technology and Engineering, 8(2 Special Issue), 271-278.

Pulimeno, M., Piscitelli, P., \& Colazzo, S. (2020). Children's literature to promote students' global development and wellbeing. Health Promotion Perspectives, 10(1), 13-23. https://doi.org/10.15171/hpp.2020.05

Rischa, F. N., Abdul, S., \& Winarno. (2019). The implantation of nationalism in globalization era using value clarification learning models. 1st International Conference on Education and Social Science Research (ICESRE 2018), 287(1), 158-160. https://doi.org/10.2991/icesre-18.2019.33

Sanchez, T. R., \& Stewart, V. (2006). The remarkable Abigail: story-telling for character education. High School Journal, 89(4), 14-21.

Shabiralyani, G., Hasan, K. S., Hamad, N., \& Iqbal, N. (2015). Impact of visual aids in enhancing the learning process case research: District Dera Ghazi Khan. Journal of Education and Practice, 6(19), 226-233.

Sofyaningsih, V. (2014). Pandangan pemilih pemula pelajar SMA Negeri 1 Wonosari dan SMA Negeri 1 Patuk terhadap bakal calon presiden versi media masa pada pilpres 2014 [Universitas Negeri Yogyakarta]. https://eprints.uny.ac.id/23767/

Spyrou, S. (2011). Children's educational engagement with nationalism in divided Cyprus. International Journal of Sociology and Social Policy, 31(9/10), 531-542. https://doi.org/10.1108/01443331111164124

Sriati, S. (2015). Pengembangan buku kumpulan cerita anak daerah lamongan untuk meningkatkan karakter siswa SD. Jurnal Media Didaktika, 1(2), 173-182.

Stewig, J. W. (2013). Children's preference in picture book illustration. Education Leadership Journal, 30(3), 273-279.

Suhartini, S., Sekarningrum, B., Sulaeman, M. M., \& Gunawan, W. (2019). Social construction of 
Jurnal Prima Edukasia, 9 (1), 2021 - 144

Moh. Farizqo Irvan, Ali Mustadi

student behavior through character education based on local wisdom. Journal of Social Studies Education Research, 10(3), 276-291. https://www.learntechlib.org/p/216467/.

Sung, H. Y., Hwang, G. J., \& Chang, H. S. (2015). An integrated contextual and web-based issue quest approach to improving students' learning achievements, attitudes and critical thinking. Educational Technology and Society, 18(4), 299-311.

Suryanti, S., Mariana, N., Yermiandhoko, Y., \& Widodo, W. (2020). Local wisdom-based teaching material for enhancing primary students' scientific literacy skill. Jurnal Prima Edukasia, 8(1), 96-105. https://doi.org/10.21831/jpe.v8i1.32898

Syarif, F. (2019). Integrasi nilai kearifan lokal terhadap penanamanan nasionalisme bagi siswa sekolah dasar. Al Amin: Jurnal Kajian Ilmu Dan Budaya Islam, 2(02), 187-195. https://doi.org/10.36670/alamin.v2i02.26

Tsai, K. C. (2012). Bring character education into classroom. European Journal of Educational Research, 1(2), 163-170. https://doi.org/10.12973/eu-jer.1.2.163

Tukiran, T. (2014). Pendidikan multikultural dan nasionalisme Indonesia. SOSIO DIDAKTIKA: Social Science Education Journal, 1(1), 29-36. https://doi.org/10.15408/sd.v1i1.1203

Turan, F., \& Ulutas, I. (2016). Using storybooks as a character education tools. Journal of Education and Practice, 7(15). https://www.iiste.org/Journals/index.php/JEP/article/view/30887

Tyra, C. (2012). Bringing books to life: Teaching character education through children's literature. Rising Tide, 5, 1-13.

Uge, S., Neolaka, A., \& Yasin, M. (2019). Development of social studies learning model based on local wisdom in improving students' knowledge and social attitude. International Journal of Instruction, 12(3), 375-388. https://doi.org/10.29333/iji.2019.12323a

USAID. (2014). Pembelajaran literasi kelas awal di LPTK. USAID PRIORITAS.

Uzakbayeva, S., Zhalgasova, S., Beisembayeva, A., Kosherbayeva, G., \& sciences. (2014). The patriotism education content at the present stage. Procedia - Social and Behavioral Sciences, 141, 675-679. https://doi.org/10.1016/j.sbspro.2014.05.118

Vallori, A. B. (2014). Meaningful learning in practice. Journal of Education and Human Development, 3(4). https://doi.org/10.15640/jehd.v3n4a18

Verhallen, M. J. A. J., \& Bus, A. G. (2011). Young second language learners' visual attention to illustrations in storybooks. Journal of Early Childhood Literacy, 11(4), 480-500. https://doi.org/10.1177/1468798411416785

Yang, C.-H., Cheng, J.-C., \& Chou, M.-J. (2016). Empowering children's creativity with the instruction of wordless picture books. European Journal of Research and Reflection in Educational Sciences, 4(7), 1-16.

Yulistia, A. (2019). Scientific-based approach pictorial storybook for eliciting creative thinking and collaborative skills. Jurnal Prima Edukasia, 7(2), 172-181.

https://doi.org/10.21831/jpe.v7i2.16297 